\title{
Local seismotectonic analysis of the July 2019 Molucca Sea earthquake sequence based on moment tensor solutions
}

\author{
Aditya Dwi Prasetio ${ }^{1 *} \mathbb{D}$, Mohammad Hasib ${ }^{1}$, Andi Amran², Syuhada ${ }^{1}$, Febty Febriani ${ }^{1}$, \\ Cinantya Nirmala Dewi ${ }^{1}$ and Titi Anggono
}

\begin{abstract}
We investigate the local seismotectonic of the Molucca Sea area using moment tensor calculations for the earthquakes that occurred in July 2019 at a depth of 10-55 km. The mainshock of Mw 6.8 occurred on July 7, followed by aftershocks until July 18, with magnitudes ranging from Mw 4.6 to Mw 5.8. Moment tensor solutions are calculated by applying Isolated Asperities (ISOLA) software using the full waveform data recorded at regional seismic stations. The analyzed frequency bands used in this study are $0.01-0.03 \mathrm{~Hz}$ and $0.04-0.05 \mathrm{~Hz}$ for the event with $\mathrm{Mw} \geq 5$ and $\mathrm{Mw}<5$, respectively. We provide validations of new moment tensor solutions for $\mathrm{Mw}<5$ events in the Molucca Sea region for the period during the earthquake sequence. The results show that thrust and oblique faults are dominant during this event, which indicate a compressional stress of divergent double subduction (DDS) of the Sangihe and Halmahera arcs. Only one full moment tensor solution reveals the normal fault mechanism, which may indicate the manifestation of strain release of compressional stress in the surrounding area. Furthermore, these results also support the previous studies suggesting that the Talaud-Mayu Ridge located in the middle of the Molucca Sea has developed as a consequence of the transpressional tectonic activity.
\end{abstract}

Keywords: Molucca Sea, Earthquake sequences, Moment tensor, Local seismotectonic

\section{Introduction}

The Molucca Sea, an area well known for its tectonic complexity, is a region with high seismicity, located between the eastern arm of Sulawesi Island and Halmahera Island in the eastern part of Indonesia (see Fig. 1a). This region lies within a complex triple junction between three major plates: the southeastern section of the Eurasian Plate, the Philippine Sea Plate, and the Australian Plate (Rangin et al. 1999; Bird 2003). The Molucca Sea Plate, one of the region's microplates, is bounded by the convergence of the Eurasian Plate in the western part and the Philippine Sea Plate in the eastern part. The Eurasian

\footnotetext{
*Correspondence: aditya.dwi.prasetio@lipi.go.id; adityadprasetio@gmail.com ${ }^{1}$ Research Center for Physics - LIPI, Kawasan PUSPIPTEK Serpong, South Tangerang, Indonesia

Full list of author information is available at the end of the article
}

Plate and the Philippine Sea Plate move to the east and west direction, respectively (e.g., Hall and Smyth 2008; Waltham et al. 2008). On the other hand, the Molucca Sea Plate is subducted under the arc-arc collision between Sangihe in the west and Halmahera in the east. This region is the only unique example of an active arcarc collision on earth that consumes an oceanic basin via subduction in a different direction. It is formed by the convergence of the Sangihe and Halmahera arcs into the Molucca Sea Plate in eastward and westward directions, respectively (see Fig. 1b). This complexity is known as the Molucca Sea Collision Zone. This double subduction system causes the Molucca Sea Plate to be consumed by the Eurasian Plate in the west and the Philippines Sea Plate in the east, and the upliftment of the Talaud-Mayu Ridge at the center of the Molucca Sea. Furthermore, the accretional complex has been thrust toward the forearc

\section{Springer Open}

(c) The Author(s) 2021. Open Access This article is licensed under a Creative Commons Attribution 4.0 International License, which permits use, sharing, adaptation, distribution and reproduction in any medium or format, as long as you give appropriate credit to the original author(s) and the source, provide a link to the Creative Commons licence, and indicate if changes were made. The images or other third party material in this article are included in the article's Creative Commons licence, unless indicated otherwise in a credit line to the material. If material is not included in the article's Creative Commons licence and your intended use is not permitted by statutory regulation or exceeds the permitted use, you will need to obtain permission directly from the copyright holder. To view a copy of this licence, visit http://creativecommons.org/licenses/by/4.0/. 


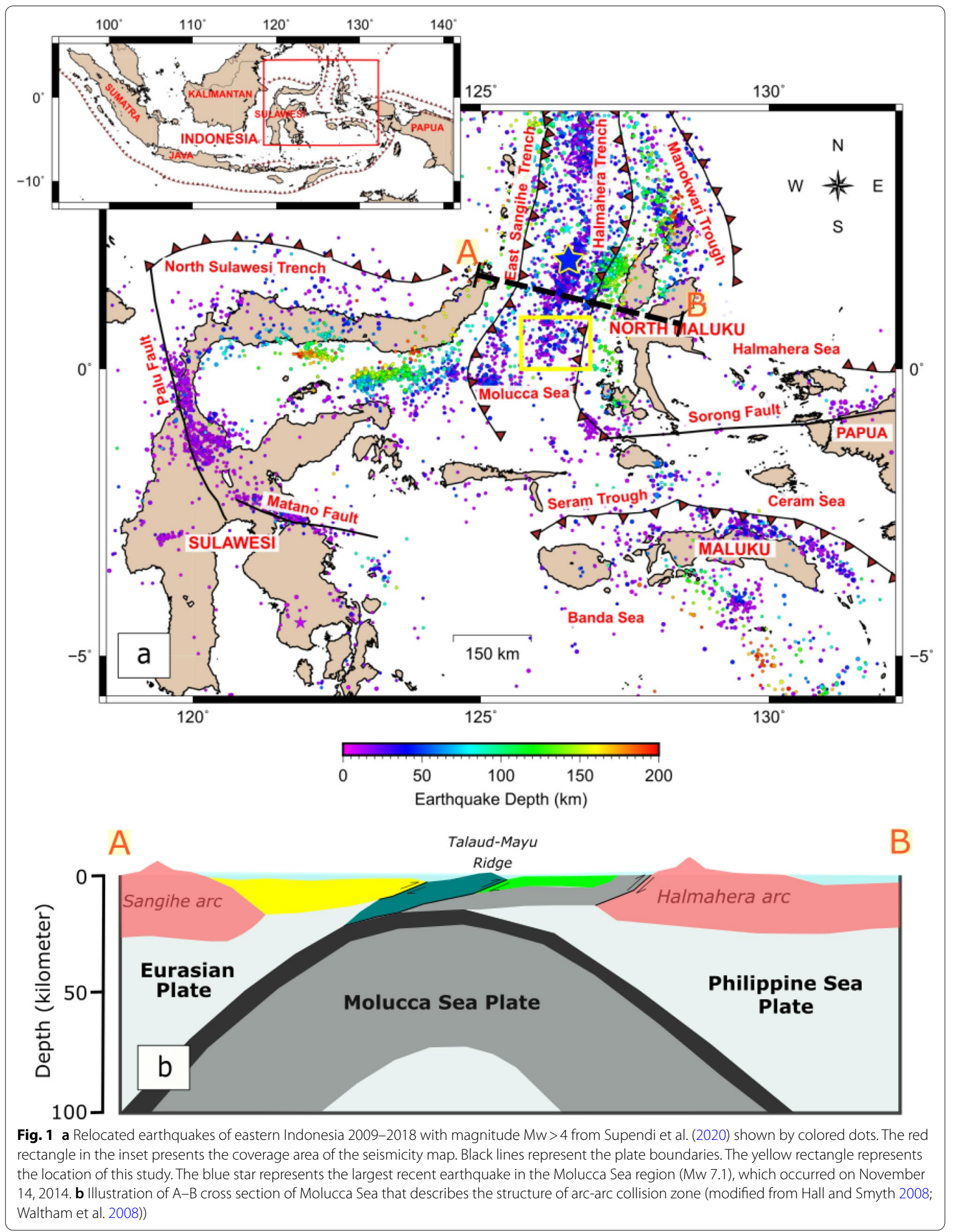


sedimentary basin (Silver and Moore 1978; Hamilton 1979; McCaffrey et al. 1980; Hall 1987, 1997; Hall and Blundell 1996; Hinschberger et al. 2005; Hall and Smyth 2008). Such condition makes the tectonic setting of Molucca unique compared to other regions.

Several studies have successfully identified the geological structure of the subsurface surrounding the Molucca Sea, as evidenced by Bouguer gravity anomaly, seismicity, and geological studies (Bemmelen 1949; Setyanta and Setiadi 2011). The geological studies show that the tectonic setting of the Molucca Sea from west to east consists of a volcanic arc ridge in northern Sulawesi (the Sangihe Ridge), a non-volcanic arc ridge in Talaud (the Talaud-Mayu Ridge), a volcanic arc ridge in northern Halmahera, and a non-volcanic arc ridge in eastern Halmahera. Several geophysical investigations have also been conducted in the Molucca Sea to get a better understanding of the area's tectonic setting. For example, the double subduction of the Molucca Sea Plate has been modeled in 3D by Zhang et al. (2017). Their results suggest that the subduction process occurs asymmetrically on the east and west sides of the slab. In addition, their model agrees well with the P-S wave travel-time tomography study of Zenonos et al. (2019), suggesting that the Sangihe slab penetrates to the lower mantle while the Halmahera slab only reaches a depth of $400-500 \mathrm{~km}$ below sea level.

Widiwijayanti et al. $(2003,2004)$ used satellite gravity data to determine the subsurface structure of the northern Molucca Sea. They identified the central ridge as an active deformed region based on the large density variation found in their research. Furthermore, the geodetic investigation suggests that the plate convergence rate between the Sangihe and Halmahera subduction systems in the Molucca Sea is estimated to be about $80 \mathrm{~mm}$ /year (Rangin et al. 1999). The latest finding, based on GPS observation of the Mw 7.1 Molucca Sea earthquake on November 14, 2014, Gunawan et al. (2016) suggests that the earthquake caused a coseismic slip of $\pm 36 \mathrm{~cm}$ around the hypocenter located in the central ridge. In other previous seismic studies conducted in the Molucca Sea, hypocenter relocation was investigated to enhance the location accuracy of earthquake events (Nugraha et al. 2015; Shiddiqi et al. 2015; Yulianto et al. 2017; Supendi et al. 2020). These studies apply the double-difference method, where the distance of two events is smaller than the distances to measuring stations, implying that they have similar ray paths (Waldhauser and Ellsworth 2000). This method can be applied to large numbers of earthquakes over large distances.

Local seismotectonic conditions in the surrounding area of the Molucca Sea are poorly understood. To explain the local seismotectonic setting in this area, we analyze an earthquake sequence that occurred in the area using regional seismic data. Analyzing the waveform inversion of mainshock and aftershock events provides a more comprehensive identification of the source mechanism (Saputra et al. 2021). An analysis of moment tensor inversion is very important to map the variety, complexity of tectonic deformation and also to understand the geodynamic process in a region. In this study, we examine 14 earthquakes with magnitude $\mathrm{Mw}>4$, the largest of which at Mw 6.8 occurred on July 7, 2019 and was also the largest earthquake in the area during 2019.

Examination of earthquake sequences based on moment tensor in this study is used to determine the seismotectonic trend of the Molucca Sea. Focal mechanism obtained from the moment tensor inversion provides a manifestation of the activity of geological structures (Stein and Wysesion 2003). The analysis of the mainshock-aftershock sequence provides information on the process of relative stress release associated with major and minor faults around the study area. The results of full-waveform inversion produce accuracy regarding the type of source mechanisms and may indicate the character of local fault structures. The moment tensor solution of full-waveform inversion can be effectively computed using ISOLA software, which has been broadly used in other seismotectonic studies (Agurto et al. 2012; Choi et al. 2012; Benetatos et al. 2013; Cambaz and Mutlu 2016; González et al. 2017; Supendi et al. 2018). This software has been developed to automatically calculate centroid moment tensor solutions (Triantafyllis et al. 2016; Vackáař et al. 2017). Thus, we employ the ISOLA software to retrieve the centroid moment tensor solutions. This study may provide important information for seismotectonic pattern in the Molucca Sea area.

\section{Data and method}

\section{Seismic stations and dataset}

In this study, we analyze seismic waveforms obtained from July 2019 Molucca Sea earthquakes sequence. The waveforms were recorded by the Indonesian Meteorological, Climatological, and Geophysical Agency (BMKG) seismic network (IA-Network). We selected the earthquake data related to July 2019 Molucca Sea earthquake using the GFZ catalog. The initial dataset used in this study is obtained from 18 broadband IA stations. Each station is equipped with a three-component broadband seismometer (NS, EW, and Z). The closest (GLMI) and farthest (BKSI) of the seismic stations are about $230 \mathrm{~km}$ and $1000 \mathrm{~km}$ away from the earthquake epicenter, respectively. The distributions of the seismic stations and sequence of earthquakes are shown in Fig. 2.

In this study, we analyze 14 earthquakes that occurred in the Molucca Sea from July 7 to July 18, 2019 (see Table 1). The obtained datasets are in Standard for the 


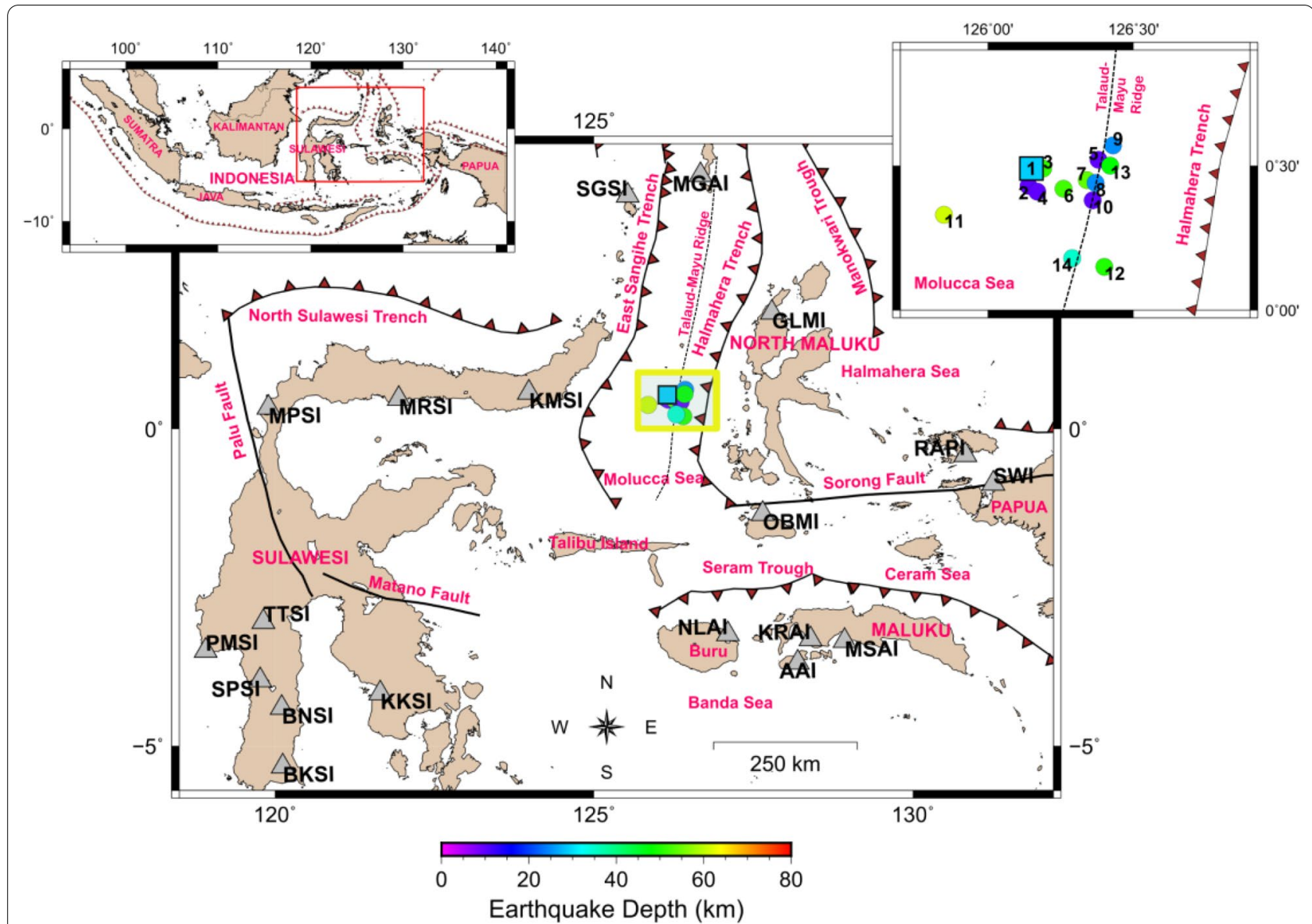

Fig. 2 The tectonic setting of study area with the black lines representing the plate boundaries and the black dashed line showing the Talaud-Mayu ridge. The inset at the right top shows the zoom-in of the yellow rectangular area in the main figure. The right top inset displays the Earthquakes with Mw > 4 in the Molucca Sea recorded during July 7-18, 2019, as shown by the colored dots and numbered in time sequence from 1 to 14. The earthquakes information is obtained from the GFZ catalog. The mainshock is indicated by a blue rectangular. The gray triangles indicate the seismic stations of the IA-Network. The inset figure at the left top of the main figure indicates the area of investigation, which is marked by the red rectangle

Table 1 Earthquake data from the GFZ catalog used for the moment tensor analysis

\begin{tabular}{|c|c|c|c|c|c|}
\hline Event & Origin time (local time) & Longitude ( $\left({ }^{\circ} \mathrm{E}\right)$ & Latitude $\left({ }^{\circ} \mathrm{N}\right)$ & Depth $(\mathrm{Km})$ & Mw \\
\hline 1 & 2019.07.07 15:08:40 & 126.15 & 0.54 & 29 & 6.8 \\
\hline 2 & 2019.07.07 15:43:59 & 126.14 & 0.48 & 10 & 5 \\
\hline 3 & 2019.07.07 17:05:20 & 126.19 & 0.54 & 51 & 4.8 \\
\hline 4 & 2019.07.08 02:49:42 & 126.17 & 0.46 & 10 & 4.6 \\
\hline 5 & 2019.07.08 04:16:17 & 126.38 & 0.57 & 10 & 4.7 \\
\hline 6 & 2019.07.08 06:20:16 & 126.26 & 0.47 & 52 & 5.6 \\
\hline 7 & 2019.07.08 18:52:36 & 126.34 & 0.5 & 54 & 5.8 \\
\hline 8 & 2019.07.08 19:00:40 & 126.37 & 0.49 & 25 & 4.9 \\
\hline 9 & 2019.07.08 19:54:11 & 126.43 & 0.62 & 25 & 4.9 \\
\hline 10 & 2019.07.08 21:30:47 & 126.36 & 0.43 & 10 & 4.6 \\
\hline 11 & 2019.07.11 10:06:41 & 125.85 & 0.38 & 61 & 4.7 \\
\hline 12 & 2019.07.11 21:24:27 & 126.4 & 0.2 & 50 & 4.7 \\
\hline 13 & 2019.07.11 21:46:41 & 126.42 & 0.55 & 48 & 4.8 \\
\hline 14 & 2019.07.18 17:17:51 & 126.29 & 0.23 & 35 & 5.2 \\
\hline
\end{tabular}


Exchange of Earthquake Data (SEED) format. We then convert these waveforms into SAC format. We check the data manually by plotting the waveforms to ensure that we process the waveforms with a good signal-to-noise ratio. The main event occurred on July 7,2019 , with a magnitude of Mw 6.8 at a depth of $29 \mathrm{~km}$ and the epicenter location about $110 \mathrm{~km}$ west of Ternate Island. This largest event was followed by 13 smaller earthquakes (magnitudes ranging from $\mathrm{Mw} 4.6$ to $\mathrm{Mw}$ 5.8) that took place within a $40 \mathrm{~km}$ radius.

\section{Method}

To provide valuable information on the deformation process, the determination of the source mechanisms requires full waveform analysis. Our determination of the earthquake mechanism is carried out using the full waveform inversion method executed by ISOLA software, which was developed by Sokos and Zahradnik (2008). Wen et al. (2015) showed that the waveform inversion could be used to obtain precise fault-plane solutions. This enables us to better understand the seismotectonic process around a region. The ISOLA software packages consist of two processing parts, which are ISOLA Fortran code and ISOLA-GUI written in MATLAB. ISOLA Fortran code is used for moment tensor calculation. On the other hand, the ISOLA-GUI interface is used for the data pre-processing and plotting. We use ISOLA in the data processing to retrieve the moment tensor parameters and identify the source mechanism of the earthquake sequences. The moment tensors are computed by minimizing the difference between synthetic and observed seismograms using the least-squares method. Then, the source mechanisms are used to interpret the local seismotectonic setting in the surrounding area of the earthquake.

The synthetic seismogram is determined by Green's functions in the Fortran code of ISOLA, which uses the discrete wavenumber method (Bouchon 1981, 2003; Coutant 1989). This method is carried out in the time-domain with the lowest-possible frequency, which reduces the effect of subsurface inaccuracy of the adopted crustal model. The calculation of Green's function using this method is applicable to the regional and local events (Sokos and Zahradnik 2008). The method optimizes the moment tensor solutions through spatiotemporal grid search conducted in two steps to find the best-fitting source position and time. First, we create a model consisting of trial point sources distributed along the vertical line below the epicenter with a depth interval of $1 \mathrm{~km}$ and a time interval of $5 \mathrm{~s}$ around the origin time with 0.1-s increments. In the second step, we design trial sources distributed along the lateral plane grid at the preferred source depth previously obtained from the first step with a grit interval of 2 to $4 \mathrm{~km}$. Since there is no appropriate velocity model around the study area, thus we use the AK135 earth model (Kennett et al. 1995) for generating synthetics that allows the inversion routine to be more reliable for this study (see Fig. 3). Consequently, this restricts the inversion to low-frequency bands that are less affected by structural heterogeneities as well as by inaccurate velocity model (Larson and Ekström 2001). Furthermore, the waveforms used for this study are also limited for low-frequency waves since we invert waveforms from low magnitude events providing signals higher than the noise level only at low-frequency waves. These two restrictions allow us to use low-frequency bands for the inversion process. The optimum moment tensor solution for the largest earthquake ( $M w ~ 6.8)$, which occurred on July 7, 2019 (event \#1), is within the range of frequency band of 0.01 to $0.03 \mathrm{~Hz}$ used in our analyses. On the other hand, the optimum moment tensor solution for the smallest earthquakes ( $\mathrm{Mw} 4.6)$, which occurred on July 8, 2019 (events \#4 and \#10), is within the range of frequency band of 0.04 to $0.05 \mathrm{~Hz}$. In this study, the optimum result shows the range of frequency band of analysis is narrower for the smaller earthquakes (see Table 2).

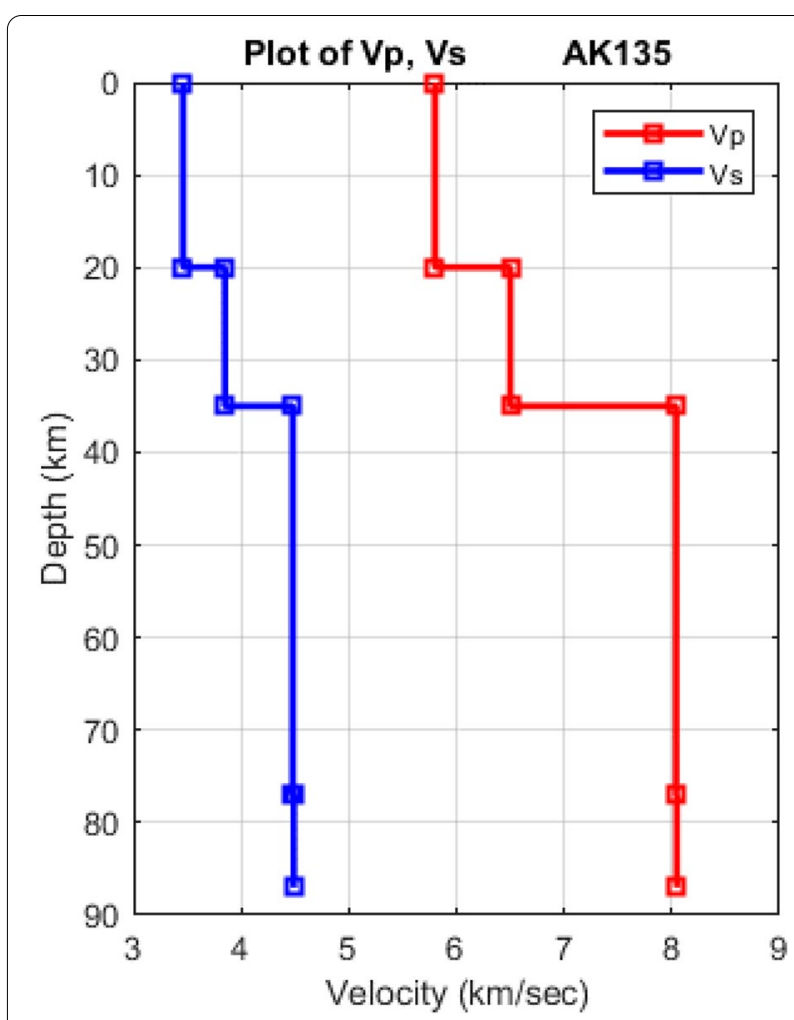

Fig. 3 The AK135 velocity model which is applied for the calculation of the Green's functions in this study and adopted from Kennett et al. (1995) 
Table 2 Frequency ranges used for the analyses in this study

\begin{tabular}{lll}
\hline Event & Frequency range $\mathbf{( H z )}$ & Analyzed seismic station \\
\hline 1 & $0.01-0.03$ & OBMI, NLAI, MRSI, KRAI, AAI, MSAI, RAPI, SWI, MPSI, KKSI, TTSI, BNSI, SPSI \\
2 & $0.04-0.05$ & GLMI, KMSI, OBMI \\
3 & $0.04-0.05$ & GLMI, KMSI, OBMI, SGSI \\
4 & $0.04-0.05$ & GLMI, KMSI, OBMI, SGSI, MRSI, MSAI, RAPI, SWI \\
5 & $0.01-0.024$ & GLMI, OBMI, KMSI, SGSI, MGAI, NLAI, KRAI, MRSI, RAPI, MSAI \\
6 & $0.01-0.02$ & GLMI, OBMI, KMSI, SGSI, MGAI, NLAI, KRAI, AAI, MSAI, RAPI, SWI \\
7 & $0.01-0.02$ & GLMI, OBMI, KMSI, SGSI, MGAI, NLAI, KRAI, AAI, RAPI, MSAI, SWI \\
8 & $0.04-0.05$ & GLMI, KMSI, SGSI, MRSI \\
9 & $0.04-0.05$ & GLMI, OBMI, KMSI, KRAI, MRSI, RAPI, SWI \\
10 & $0.04-0.05$ & GLMI, OBMI, KMSI, MRSI, RAPI, SWI \\
11 & $0.03-0.045$ & GLMI, SGSI, KRAI, MSAI, RAPI \\
12 & $0.04-0.05$ & OBMI, GLMI, KMSI, RAPI, MRSI \\
13 & $0.01-0.02$ & GLMI, KMSI, MRSI, RAPI, AAI \\
14 & $0.01-0.02$ & OBMI, GLMI, KMSI, SGSI, NLAI, MGAI, KRAI, MRSI, AAI, MSAI, RAPI, SWI \\
\hline
\end{tabular}

The double-couple (DC) percentage of the moment tensor solution indicates how good the inversion result is. The selection of the best-fit solution considers the highest correlation with the optimum DC parameter. A previous study shows that the double-couple percentage of less than $0.5(\mathrm{DC}<0.5)$ provides significant uncertainty relating to the focal mechanism (Carvalho et al. 2016). The quality of the moment tensor solution is eventually inspected by the variance reduction (VR), which measures the residual between the observed and synthetic waveforms. The VR value is good if it is higher than 0.4 (VR > 0.4) (Sokos and Zahradnik 2008). We also calculate condition number $(\mathrm{CN})$, which shows the resolvability of the moment tensor solution. A smaller $\mathrm{CN}$ value indicates better resolvability (for the exact value, see Křížová et al. 2013). Thus, the best solution is selected as that with the highest VR and DC but the smallest $\mathrm{CN}$, which represents the best fit between observed and synthetic waveforms. The best solutions will be interpreted to understand the local seismotectonic setting of the July 2019 Molucca Sea earthquake sequence.

\section{Results and discussion}

\section{Moment tensor solutions}

An example of observed and synthetic waveforms from the earthquake sequence moment tensor analysis is shown in Fig. 4. The best-fitting solution between observed and synthetic waveforms is indicated by the parameters of VR, DC, and CN (see Table 3). We only examine moment tensor solutions with high $\mathrm{VR}$ and $\mathrm{DC}$ values and low $\mathrm{CN}$ values. In this study, most of the results have VR and DC values higher than 0.4 and 0.6 , respectively, and $\mathrm{CN}$ values below 6 . This suggests that our inversion results are well fit for the observed waveforms.

Our fault-plane solutions of the July 2019 Molucca Sea earthquake sequence are shown in Fig. 5. The results of moment tensors show that the epicenter depths can be classified as shallow earthquakes based on the earthquake depth classification of Spence et al. (1989) with a depth range of 10-63 km (see Table 4). We observe that some events show differences in focal depth between our inversion result and the earthquake catalog (Table 4). This is also observed by many previous studies (e.g., Semmane et al. 2005; Bai et al. 2017; González et al. 2017; Jian et al. 2018). We suggest that the differences may be due to lack of station coverage and complex velocity structure in the region. In this study, all tectonic activities occur in the upper lithosphere and the Molucca Sea Plate, according to the cross-section of tectonic settings used by Silver and Moore (1978) and Zhang et al. (2017). McCaffrey et al. (1980) suggested that the tectonic regime in the upper lithosphere at this region has a thrust fault pattern with general azimuth of fault plane in the NNE-SSW direction.

Our results suggest that a transpressional structure pattern with the NE-SW strike direction is the major pattern in this area, such as shown by the \#1, \#5, \#7, \#12, $\# 13$, and \#14 events. The strike-slip structure pattern for the major fault plane is $\mathrm{N}-\mathrm{S}$ direction, as indicated by events \#2, \#3, \#6, and \#8. The compressional structure pattern with the major fault plane of NW-SE azimuth is depicted by events \#4, \#9, and \#10. On the other hand, event \#11 has a tensional structure pattern in the form of a normal fault, which may correlate to the strain release structure from the compressional force in this area. 


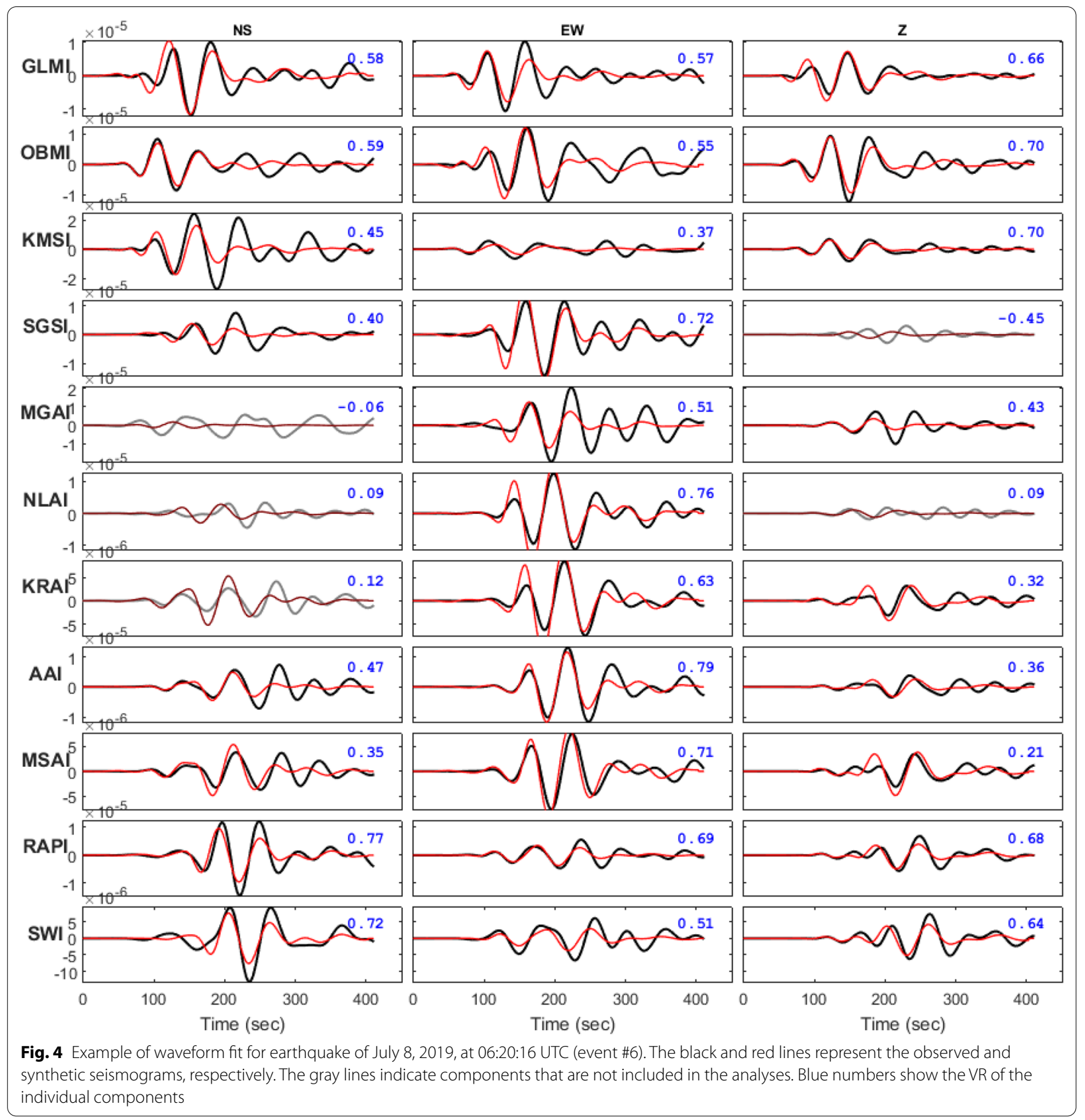

Therefore, we suggest that this earthquake cluster maps the existence of a major fault plane dominated by thrust movements.

Figure 5a depicts the interpretation of the fault plane solutions of all earthquakes in this study. It reveals the main structure pattern of thrust fault orienting NE-SW. This thrust fault elongates in the middle of the Molucca Sea and may contribute to the uplift of the Mayu Island, which is located in the northern side of the study area. A cross section of this major structure. as shown in Fig. 5b may indicate the presence of a west dipping thrust fault structure delineated under the Molucca Sea. This interpreted thrust fault system is represented by the ten compressional structures obtained from our inversion result. Different orientation of the thrust faults is suggested as the segmentation of the structure in the same fault zone under the same compressional regime. This finding is consistent with the geological interpretation from 
Table 3 Comparison of the moment tensor solutions derived from GFZ, GCMT, and this study

\begin{tabular}{|c|c|c|c|c|c|c|c|c|c|c|c|}
\hline Event & $\begin{array}{c}\text { Mw } \\
\text { (GFZ) } \\
\text { (GCMT) } \\
\text { (this study) }\end{array}$ & $\begin{array}{c}\text { Moment } \\
\text { tensor } \\
\text { GFZ }\end{array}$ & $\begin{array}{l}\text { Moment } \\
\text { tensor } \\
\text { GCMT }\end{array}$ & $\begin{array}{l}\text { Moment } \\
\text { tensor } \\
\text { this } \\
\text { study }\end{array}$ & $\begin{array}{c}\text { Strike1 Dip1 Rake1 } \\
\text { (GFZ) } \\
\text { (GCMT) } \\
\text { (this study) }\end{array}$ & $\begin{array}{c}\text { Strike2 Dip2 Rake2 } \\
\text { (GFZ) } \\
\text { (GCMT) } \\
\text { (this study) }\end{array}$ & $\begin{array}{l}\text { DC\% } \\
\text { GFZ }\end{array}$ & $\begin{array}{c}\text { DC\% } \\
\text { GCMT }\end{array}$ & $\begin{array}{l}\text { DC\% } \\
\text { this } \\
\text { study }\end{array}$ & $\begin{array}{l}\text { VR\% } \\
\text { this } \\
\text { study }\end{array}$ & $\begin{array}{l}\text { CN } \\
\text { this } \\
\text { study }\end{array}$ \\
\hline \multirow{3}{*}{1} & 6.8 & & & & 24453126 & 3535052 & & & & & \\
\hline & 6.9 & & & & 22864135 & 3425135 & 96.4 & 36 & 68.7 & 58 & 1.9 \\
\hline & 6.8 & & & & 22660127 & 3494644 & & & & & \\
\hline \multirow{3}{*}{5} & 4.7 & & & & 15950101 & 3224277 & & & & & \\
\hline & 5 & & & & 17143103 & 3334878 & 56.6 & 78.2 & 68.4 & 61 & 2.0 \\
\hline & 4.6 & & & & 1625979 & 432109 & & & & & \\
\hline \multirow{3}{*}{6} & 5.6 & & & & 3458010 & 25380170 & & & & & \\
\hline & 5.7 & & & & 3447911 & 25280169 & 97.9 & 93.5 & 95.2 & 54 & 3.4 \\
\hline & 5.5 & & & & 3517218 & 25573161 & & & & & \\
\hline \multirow{3}{*}{7} & 5.8 & & & & 1904084 & 185095 & & & & & \\
\hline & 5.9 & & & & 1863174 & 2561100 & 48.0 & 42.5 & 63.9 .8 & 58 & 2.5 \\
\hline & 5.8 & & & & 1863074 & 256199 & & & & & \\
\hline \multirow{3}{*}{12} & - & & & & - & --- & & & & & \\
\hline & 5 & & & & 21938137 & 3466560 & - & 66.3 & 78.2 & 62 & 3.4 \\
\hline & 4.9 & & & & 19072108 & 3242647 & & & & & \\
\hline \multirow{3}{*}{13} & - & & & & --- & --- & & & & & \\
\hline & 5.3 & & & & 2092953 & 6967108 & - & 77.1 & 95.1 & 52 & 3.6 \\
\hline & 4.8 & & & & 2123474 & 5157100 & & & & & \\
\hline \multirow{3}{*}{14} & 5.2 & & & & 2185193 & 333986 & & & & & \\
\hline & 5.3 & & & & 1954454 & 6056119 & 87.2 & 96.9 & 93.4 & 53 & 4.3 \\
\hline & 5.2 & & & & 2044667 & 5549112 & & & & & \\
\hline
\end{tabular}

the studies conducted by Hall and Smyth (2008) and Waltham et al. (2008) as shown in the geological tectonic cross-section across the Molucca Sea region (see Fig. 1b). They suggest that the presence of trust faulting zone around the area may be associated with the Talaud-Mayu ridge above the crest of the Molucca Sea Plate.

In this study, we observe several distinct fault planes during the July 2019 Molucca Sea earthquakes sequences. This condition may be interpreted as an event on July 7 , 2019, that is considered as a mainshock. The event may be associated with a transpressional movement that resulted from the stress release process on the major fault. The mainshock may be triggered by the movement of the fault structures in the surrounding area based on the static stress change. Assuming that aftershocks are triggered by a change in static stress, then there is a shift on the mainshock fault that causes shear stress change in the surrounding area. If the shear stress change exceeds the coefficient of static friction, this will trigger a compressional movement. In contrast, if the shear stress is significantly reduced, a tensional (normal fault) movement will be triggered.

The obtained 13-moment tensor solutions represent the compressional force and shear stress on the sedimentary basin between the Sangihe and Halmahera arcs. The thrust fault mechanism within the north-south azimuth is the main structure combined with the strike-slip fault mechanism. On the other hand, event \#11 has tensional stress as a normal fault mechanism, which has different principal stress to the other events. This event may be determined as the strain release of compressional and shear-stress mechanisms in this region. We infer that tectonic activity with the compressional regime in this area may control the uplift of the Talaud-Mayu Ridge, which is elongated on the north-south azimuth in the middle of the Molucca Sea caused by the over-thrusting of the sedimentary basin. This result is in good agreement with the previous studies (Silver and Moore 1978; McCaffrey et al. 1980; Hall and Smyth 2008), suggesting that the thrust faulting in the middle Molucca Sea is associated with the development of the Talaud-Mayu Ridge.

\section{Comparison of moment tensor between our result and global data}

In this study, the GFZ catalog provides a moment tensor solution of five events (events \#1, \#5, \#6,\#7, and \#14) based on the calculation by Saul et al. (2011). Meanwhile, the GCMT presents that of seven events (events $\# 1$, \#5, \#6, \#7, \#12, \#13, and \#14) (Dziewonski et al. 1981; Ekström et al. 2012). We compute the percentage of double-couple (DC) components of GCMT and GFZ catalogs using Vavryčuk's $(2001,2015)$ calculation (see Eq. 1). The percentage of DC data is expressed as: 

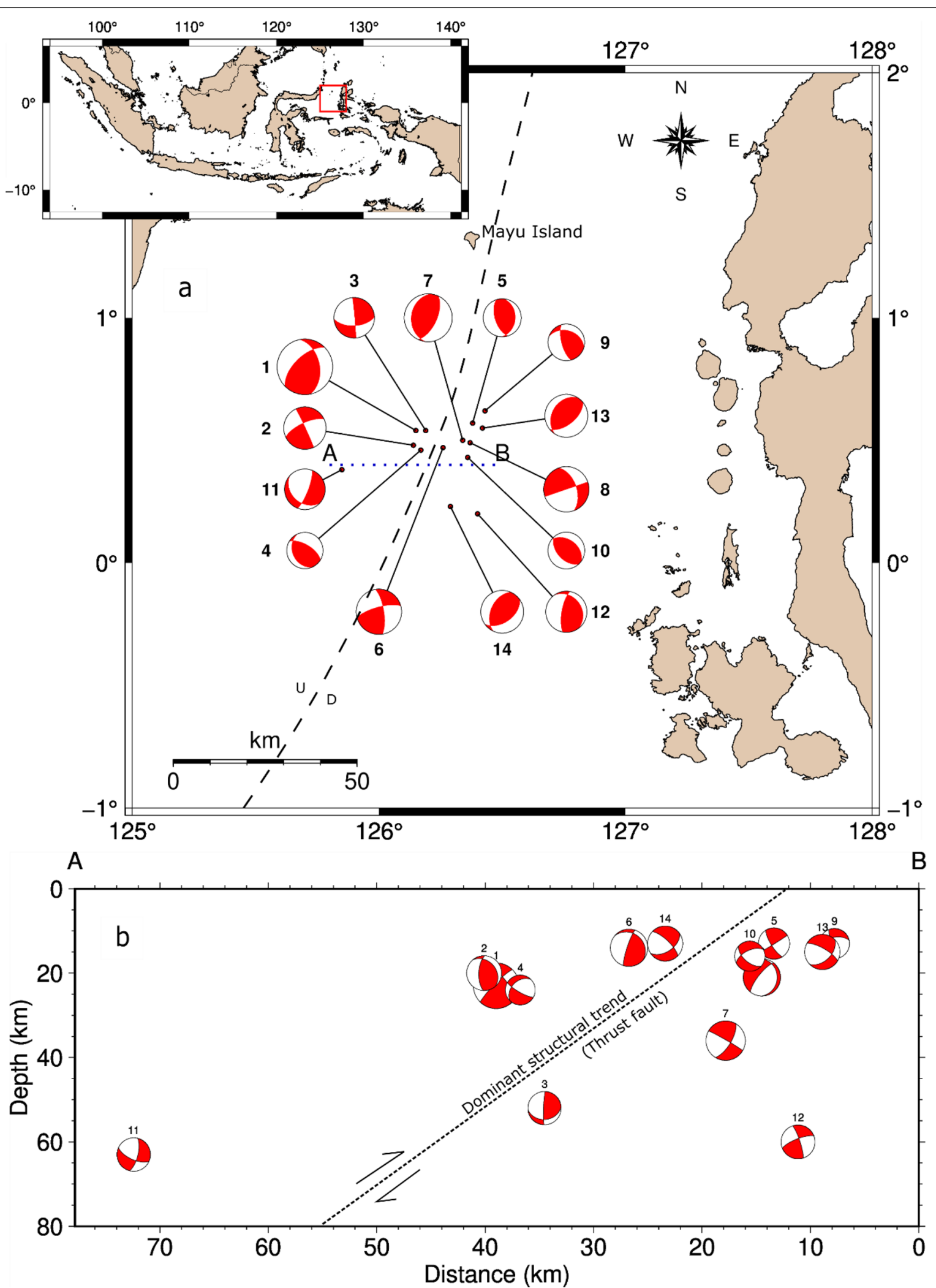

Fig. 5 The fault-plane solutions of all earthquakes in this study. a The numbers indicate the events as referred to in Table 1. The red rectangle in the inset map presents the study area. The dominant focal mechanisms have the dominant relative structural plane of northeast-southwest azimuth. $\mathbf{b}$ The A-B cross-section shows the dominant geological structure trend of the thrust fault marked by the dash line 
Table 4 New focal mechanisms of this study with the location and focal depth comparison to the GFZ catalog

\begin{tabular}{|c|c|c|c|c|c|c|c|c|c|c|c|}
\hline$\#$ & $\begin{array}{c}\text { Lon-Lat-Depth } \\
\text { (GFZ) } \\
\text { (GCMT) } \\
\text { (this study) } \\
\end{array}$ & $\begin{array}{c}\Delta(\mathbf{K m}) \\
\operatorname{Min}- \\
\max \end{array}$ & Mw & $\begin{array}{c}\text { Moment } \\
\text { tensor }\end{array}$ & $\begin{array}{l}\text { Strike1 } \\
\text { Strike2 }\end{array}$ & $\begin{array}{l}\text { Dip1 } \\
\text { Dip2 }\end{array}$ & $\begin{array}{l}\text { Rake1 } \\
\text { Rake2 }\end{array}$ & DC\% & VR\% & NC & $\mathbf{C N}$ \\
\hline 1 & $\begin{array}{l}126.15-0.40-29 \\
126.10-0.55-30 \\
126.15-0.54-23\end{array}$ & $266-932$ & 6.8 & & $\begin{array}{l}226 \\
349\end{array}$ & $\begin{array}{l}60 \\
46\end{array}$ & $\begin{array}{c}127 \\
44\end{array}$ & 68.7 & 58 & 43 & 1.9 \\
\hline 2 & $\begin{array}{c}\text { 126.14-0.48-10 } \\
\text {--- } \\
\text { 126.02-0.39-20 }\end{array}$ & $237-262$ & 5.2 & & $\begin{array}{l}335 \\
245\end{array}$ & $\begin{array}{l}88 \\
70\end{array}$ & $\begin{array}{c}20 \\
178\end{array}$ & 96.9 & 47 & 4 & 1.9 \\
\hline 3 & $\begin{array}{c}126.19-0.54-51 \\
- \\
126.06-0.54-52\end{array}$ & $229-356$ & 5.0 & & $\begin{array}{c}355 \\
87\end{array}$ & $\begin{array}{l}88 \\
58\end{array}$ & $\begin{array}{c}-32 \\
-177\end{array}$ & 85.5 & 49 & 7 & 3.5 \\
\hline 4 & $\begin{array}{c}\text { 126.17-0.46-10 } \\
\text {--- } \\
126.13-0.43-24\end{array}$ & $236-585$ & 4.4 & & $\begin{array}{l}156 \\
301\end{array}$ & $\begin{array}{l}32 \\
63\end{array}$ & $\begin{array}{c}121 \\
72\end{array}$ & 80.4 & 44 & 18 & 2.7 \\
\hline 5 & $\begin{array}{l}126.38-0.57-10 \\
126.36-0.81-28 \\
126.25-0.52-13\end{array}$ & $210-518$ & 4.7 & & $\begin{array}{c}162 \\
4\end{array}$ & $\begin{array}{l}59 \\
32\end{array}$ & $\begin{array}{c}79 \\
109\end{array}$ & 68.4 & 61 & 10 & 2.0 \\
\hline 6 & $\begin{array}{l}126.26-0.47-52 \\
126.23-0.52-27 \\
126.26-0.47-14\end{array}$ & $228-576$ & 5.7 & & $\begin{array}{l}255 \\
351\end{array}$ & $\begin{array}{l}73 \\
72\end{array}$ & $\begin{array}{c}161 \\
18\end{array}$ & 95.2 & 54 & 26 & 3.4 \\
\hline 7 & $\begin{array}{l}126.34-0.50-36 \\
126.38-0.35-20 \\
126.52-0.41-36\end{array}$ & $219-568$ & 5.9 & & $\begin{array}{c}186 \\
25\end{array}$ & $\begin{array}{l}30 \\
61\end{array}$ & $\begin{array}{l}74 \\
99\end{array}$ & 63.9 .8 & 58 & 11 & 2.5 \\
\hline 8 & $\begin{array}{c}126.37-0.49-25 \\
--- \\
126.33-0.31-21\end{array}$ & $217-493$ & 5.6 & & $\begin{array}{l}341 \\
251\end{array}$ & $\begin{array}{l}53 \\
90\end{array}$ & $\begin{array}{l}-180 \\
-37\end{array}$ & 63.0 & 58 & 5 & 2.8 \\
\hline 9 & $\begin{array}{c}126.43-0.62-25 \\
--- \\
126.39-0.57-13\end{array}$ & $202-562$ & 4.5 & & $\begin{array}{l}165 \\
287\end{array}$ & $\begin{array}{l}69 \\
36\end{array}$ & $\begin{array}{c}120 \\
38\end{array}$ & 52.1 & 49 & 14 & 2.8 \\
\hline 10 & $\begin{array}{c}\text { 126.36-0.43-10 } \\
\text {--- } \\
126.32-0.52-16\end{array}$ & $222-564$ & 4.5 & & $\begin{array}{l}306 \\
137\end{array}$ & $\begin{array}{l}40 \\
50\end{array}$ & $\begin{array}{l}81 \\
97\end{array}$ & 43.5 & 49 & 13 & 2.6 \\
\hline 11 & $\begin{array}{c}125.85-0.38-61 \\
--- \\
125.67-0.52-63\end{array}$ & $269-560$ & 5.0 & & $\begin{array}{c}21 \\
132\end{array}$ & $\begin{array}{l}77 \\
34\end{array}$ & $\begin{array}{l}-59 \\
-156\end{array}$ & 95.1 & 66 & 6 & 4.1 \\
\hline 12 & $\begin{array}{l}126.40-0.20-50 \\
126.49-0.38-28 \\
126.40-0.15-60\end{array}$ & $220-497$ & 5.0 & & $\begin{array}{l}190 \\
324\end{array}$ & $\begin{array}{l}72 \\
26\end{array}$ & $\begin{array}{c}108 \\
59\end{array}$ & 78.2 & 62 & 11 & 3.4 \\
\hline 13 & $\begin{array}{l}126.42-0.55-48 \\
126.37-0.15-21 \\
126.42-0.37-14\end{array}$ & $208-508$ & 5.3 & & $\begin{array}{c}212 \\
51\end{array}$ & $\begin{array}{l}34 \\
57\end{array}$ & $\begin{array}{c}74 \\
100\end{array}$ & 95.1 & 52 & 21 & 3.6 \\
\hline 14 & $\begin{array}{l}126.29-0.23-18 \\
126.32-0.16-22 \\
126.28-0.13-13\end{array}$ & $262-565$ & 5.3 & & $\begin{array}{c}204 \\
55\end{array}$ & $\begin{array}{l}46 \\
49\end{array}$ & $\begin{array}{c}67 \\
112\end{array}$ & 93.4 & 53 & 26 & 4.3 \\
\hline
\end{tabular}




$$
\mathrm{DC}(\%)=\frac{1}{M}\left(M_{\mathrm{DC}}\right) \times 100 \%
$$

where $M$ is the total scalar seismic moment, and $M_{D C}$ is the scalar seismic moment of DC component computed as the function of the eigenvalue of a seismic event (see Vavryčuk 2015).

We then examine the accuracy of our inversion solutions by comparing them with those published in global catalogs (GCMT and GFZ), as shown by Table 3. We found that the double-couple percentages of the events obtained in this study are generally comparable to those obtained from the global catalogs. However, the double-couple percentages for events \#1 and \#7 differ from GCMT and GFZ. These differences may explain the differences in the orientation of the source mechanism as indicated by the differences of eigenvalue between the results (Dahm and Krüger 2014; Vavryčuk 2015).

Furthermore, our study provides the completeness of moment tensor solution for lower magnitude portion during the July 2019 Molucca Sea earthquake sequence with reliable moment tensor solution condition. However, it is difficult to precisely determine the source parameter of small earthquakes, such as moment magnitude, due to the lack of data quality. Hence, we calculate local magnitude (ML) to compare with our new moment magnitude $(\mathrm{Mw})$ from the inversion result. $\mathrm{ML}$ is commonly used to estimate the size of an earthquake precisely due to less affected by attenuation. In this analysis, we compare our newly obtained moment magnitude $(\mathrm{Mw})$ from moment tensor solution with local magnitude (ML) to clarify the scaling relationship, especially for the lower magnitude portion. We clearly explain this analysis and its result in Additional file 1.

\section{Conclusion}

The moment tensor solutions from the Mw 6.8 July 7, 2019, Molucca Sea earthquake and its 13 aftershocks with $\mathrm{Mw}>4$ occurring along the Mayu Ridge have been computed using regional full-waveform inversion. We present 14 focal mechanisms to give a better comprehension of source mechanisms from the earthquake sequence occurring in the July 2019. Our results are complementing the GCMT and GFZ moment tensor solutions i.e., events \#2, $\# 3$, \#4, \#8, \#9, \#10, and \#11. In general, we obtain good and reliable moment tensor solutions in this analysis, as shown by high DC and VR percentages, and small $\mathrm{CN}$ values. The obtained focal mechanisms for the July 2019 Molucca Sea earthquake sequence indicate domination of thrust and strike-slip faults mechanism. There is only one normal fault event which possibly associated with strain release in the study area. The earthquake sequence occurs at shallow depth $(<70 \mathrm{~km})$ and lies below the sedimentary basin of the Molucca Sea Plate. Therefore, we interpret that the moment tensor solutions obtained from this study indicate the presence of a major thrust fault system combined with the strike-slip mechanism, which may be responsible for the development of the Talaud-Mayu Ridge. In addition, the normal faulting occurring in this area may act as a minor mechanism representing the strain release of the compressional and strike-slip stresses. We may assume that the tectonic setting did not change significantly since the sequence of our analyses occurred within one month. Thus, this study provides updated information about the seismotectonic pattern during the July 2019 Molucca Sea earthquake sequence.

\section{Supplementary Information}

The online version contains supplementary material available at https://doi. org/10.1186/s40562-021-00200-z.

Additional file 1. Relationship between Mw and ML.

\section{Acknowledgements}

The authors would like to thank E. Sokos and J. Zahradnik for providing the ISOLA software. GMT software (Wessel et al. 2019) was used in all maps and figures in this paper. The seismic waveforms used in this study are from the IA network which is operated by the Indonesian Meteorology, Climatology, and Geophysical Agency (BMKG). The moment tensor solutions used for comparison are collected from the GCMT project and GFZ German Research Centre for Geosciences.

\section{Authors' contributions}

ADP and TA initiated the research idea. AA collected data and controlled the data quality. ADP, MH, and CND performed the data processing and analyzed the result. All authors discussed the interpretation of the data processing result. $\mathrm{ADP}$ and $\mathrm{MH}$ wrote the manuscript. TA, FF, and $\mathrm{S}$ contributed to the writing and revisions. All authors read and approved the final manuscript.

\section{Funding}

This research is partly supported by the 2021 National Research Priority Program (Grant Number: B-10316/IPK/UM.01.03/XI/2020), Deputy of Earth Science, Indonesian Institute of Sciences (LIPI) awarded to FF.

Availability of data and materials

The data are maintained by the Indonesian Meteorology, Climatology, and Geophysics Agency and are available upon request.

\section{Declarations}

\section{Competing interests}

The authors declare no conflicts of interest.

\section{Author details}

${ }^{1}$ Research Center for Physics - LIPI, Kawasan PUSPIPTEK Serpong, South Tangerang, Indonesia. ${ }^{2}$ Indonesian Agency for Meteorology, Climatology and Geophysics, Jl. Angkasa I, No. 2, Kemayoran, Jakarta, Indonesia.

Received: 4 May 2021 Accepted: 27 September 2021

Published online: 26 October 2021

\section{References}

Agurto H, Rietbrock A, Ryder I, Miller M (2012) Seismic-afterslip characterization of the 2010 MW 8.8 Maule, Chile, earthquake based on moment 
tensor inversion. Geophys Res Lett 39:1-6. https://doi.org/10.1029/2012G L053434

Bai L, Li G, Khan NG et al (2017) Focal depths and mechanisms of shallow earthquakes in the Himalayan-Tibetan region. Gondwana Res 41:390-399. https://doi.org/10.1016/j.gr.2015.07.009

van Bemmelen RW (1949) The Geology of Indonesia. V.F.A. Government Printing Office, The Hague

Benetatos C, Málek J, Verga F (2013) Moment tensor inversion for two micro-earthquakes occurring inside the Háje gas storage facilities, Czech Republic. J Seismol 17:557-577. https://doi.org/10.1007/ s10950-012-9337-0

Bird P (2003) An updated digital model of plate boundaries. Geochem Geophys Geosyst. https://doi.org/10.1029/2001GC000252

Bouchon M (1981) A simple method to calculate Green's functions for elastic layered media. Bull Seismol Soc Am 71:959-971

Bouchon M (2003) A review of the discrete wavenumber method. Pure Appl Geophys 160:445-465. https://doi.org/10.1007/PL00012545

Cambaz MD, Mutlu AK (2016) Regional moment tensor inversion for earthquakes in Turkey and its surroundings: 2008-2015. Seismol Res Lett 87:1082-1090. https://doi.org/10.1785/0220150276

Carvalho J, Barros L, Portela Fontenele D (2016) Determination of the focal mechanisms of events in Brazil Central. In: Conference: Simpósio Brasileiro de Geofísica. Simpósio Brasileiro de Geofísica, pp 1-4

Choi H, Hong TK, He X, Baag CE (2012) Seismic evidence for reverse activation of a paleo-rifting system in the East Sea (Sea of Japan). Tectonophysics 572-573:123-133. https://doi.org/10.1016/j.tecto.2011.12.023

Coutant O (1989) Numerical study of the diffraction of elastic waves by fluidfilled cracks. J Geophys Res. https://doi.org/10.1029/jb094ib12p17805

Dahm T, Krüger F (2014) IS 3.9: Moment tensor inversion and moment tensor interpretation. In: New manual of seismological observatory practice 2, 2nd Web ed. GFZ German Research Centre for Geosciences, pp 1-33

Dziewonski AM, Chou TA, Woodhouse JH (1981) Determination of earthquake source parameters from waveform data for studies of global and regional seismicity. J Geophys Res 86:2825-2852. https://doi.org/10.1029/JB086 iB04p02825

Ekström G, Nettles M, Dziewoński AM (2012) The global CMT project 2004 2010: centroid-moment tensors for 13,017 earthquakes. Phys Earth Planet Inter 200-201:1-9. https://doi.org/10.1016/j.pepi.2012.04.002

González OL, Clouard V, Zahradnik J (2017) Moment tensor solutions along the central Lesser Antilles using regional broadband stations. Tectonophysics 717:214-225. https://doi.org/10.1016/j.tecto.2017.06.024

Gunawan E, Kholil M, Meilano I (2016) Splay-fault rupture during the 2014 Mw7.1 Molucca Sea, Indonesia, earthquake determined from GPS measurements. Phys Earth Planet Inter 259:29-33. https://doi.org/10.1016/j. pepi.2016.08.009

Hall R (1987) Plate boundary evolution in the Halmahera region, Indonesia. Tectonophysics 144:337-352. https://doi.org/10.1016/0040-1951(87) 90301-5

Hall R (1997) Cenozoic plate tectonic reconstructions of SE Asia. Geol Soc Spec Publ 126:11-23. https://doi.org/10.1144/GSL.SP.1997.126.01.03

Hall R, Blundell D (1996) Tectonic Evolution of SE Asia: introduction. In: Hall R, Blundell D (eds) Tectonic Evolution of SE Asia. The Geological Society, London, pp vii-xiii

Hall R, Smyth HR (2008) Cenozoic arc processes in Indonesia: identification of the key influences on the stratigraphic record in active volcanic arcs. Spec Pap Geol Soc Am 436:27-54. https://doi.org/10.1130/2008.2436(03)

Hamilton W (1979) Tectonics of the Indonesian Region. US Government Printing Office, Washington

Hinschberger F, Malod JA, Réhault JP et al (2005) Late Cenozoic geodynamic evolution of eastern Indonesia. Tectonophysics 404:91-118. https://doi. org/10.1016/j.tecto.2005.05.005

Jian PR, Tseng TL, Liang WT, Huang PH (2018) A new automatic full-waveform regional moment tensor inversion: algorithm and its applications in the Taiwan area. Bull Seismol Soc Am 108:573-587. https://doi.org/10.1785/ 0120170231

Kennett BLN, Engdahl ER, Buland R (1995) Constraints on seismic velocities in the Earth from traveltimes. Geophys J Int 122:108-124. https://doi.org/10. 1111/j.1365-246X.1995.tb03540.x

Kř́žová D, Zahradník J, Kiratzi A (2013) Resolvability of isotropic component in regional seismic moment tensor inversion. Bull Seismol Soc Am 103:2460-2473. https://doi.org/10.1785/0120120097
Larson EWFF, Ekström G (2001) Global models of surface wave group velocity. Pure Appl Geophys 158:1377-1399. https://doi.org/10.1007/PL00001226 McCaffrey R, Silver EA, Raitt RW (1980) Crustal structure of the Molucca Sea collision zone, Indonesia. Tecton Geol Evol Southeast Asian Seas Islands Part 1:161-177. https://doi.org/10.1029/gm023p0161

Nugraha AD, Shiddiqi HA, Widiyantoro S et al (2015) Preliminary results of teleseismic double-difference relocation of earthquakes around Indonesian archipelago region. AIP Conf Proc. https://doi.org/10.1063/1.4915010

Rangin C, Le Pichon X, Mazzotti S et al (1999) Plate convergence measured by GPS across the Sundaland/Philippine Sea Plate deformed boundary: the Philippines and eastern Indonesia. Geophys J Int 139:296-316. https:// doi.org/10.1046/j.1365-246X.1999.00969.x

Saputra H, Wahyudi W, Suardi I et al (2021) The waveform inversion of mainshock and aftershock data of the 2006 M6.3 Yogyakarta earthquake. Geosci Lett. https://doi.org/10.1186/s40562-021-00176-w

Saul J, Becker J, Hanka W (2011) Global moment tensor computation at GFZ Potsdam. In: AGU Fall Meeting Abstracts. pp S51A-2202

Semmane F, Cotton F, Campillo M (2005) The 2000 Tottori earthquake: a shallow earthquake with no surface rupture and slip properties controlled by depth. J Geophys Res Solid Earth 110:1-13. https://doi.org/10.1029/ 2004JB003194

Setyanta B, Setiadi A (2011) Model struktur subduksi kerak di perairan Laut Maluku dan vulkanisme berdasarkan analisis gaya berat dan kegempaan. J Geol Dan Sumberd Miner 21:213-223

Shiddiqi HA, Widiyantoro S, Nugraha AD et al (2015) Preliminary result of teleseismic double-difference relocation of earthquakes in the Molucca collision zone with a 3D velocity model. AIP Conf Proc. https://doi.org/10. 1063/1.4915019

Silver EA, Moore JC (1978) The Molucca Sea collision zone, Indonesia. J Geophys Res Solid Earth 83:1681-1691. https://doi.org/10.1029/jb083ib04p 01681

Sokos EN, Zahradnik J (2008) ISOLA a Fortran code and a Matlab GUI to perform multiple-point source inversion of seismic data. Comput Geosci 34:967-977. https://doi.org/10.1016/j.cageo.2007.07.005

Spence W, Sipkin SA, Choy GL (1989) Measuring the size of an earthquake. Earthq Inf Bull 21:58-63

Stein S, Wysesion M (2003) An introduction to seismology, earthquakes, and earth structure. Blackwell Publishing Ltd, New Jersey

Supendi P, Nugraha AD, Puspito NT et al (2018) Identification of active faults in West Java, Indonesia, based on earthquake hypocenter determination, relocation, and focal mechanism analysis. Geosci Lett. https://doi.org/10. 1186/s40562-018-0130-y

Supendi P, Nugraha AD, Widiyantoro S et al (2020) Relocated aftershocks and background seismicity in eastern Indonesia shed light on the 2018 Lombok and Palu earthquake sequences. Geophys J Int 221:1845-1855. https://doi.org/10.1093/gji/ggaa118

Triantafyllis N, Sokos E, llias A, Zahradník J (2016) Scisola: automatic moment tensor solution for SeisComP3. Seismol Res Lett 87:157-163. https://doi. org/10.1785/0220150065

Vackáař J, Burjáanek J, Gallovič F et al (2017) Bayesian ISOLA: new tool for automated centroid moment tensor inversion. Geophys J Int 210:693-705. https://doi.org/10.1093/gji/ggx158

Vavryčuk V (2001) Inversion for parameters of tensile earthquakes. J Geophys Res 106:16339-16355

Vavryčuk V (2015) Moment tensor decompositions revisited. J Seismol 19:231-252. https://doi.org/10.1007/s10950-014-9463-y

Waldhauser F, Ellsworth WL (2000) A double-difference earthquake location algorithm: method and application to the northern Hayward Fault, California. Bull Seismol Soc Am 90:1353-1368. https://doi.org/10.1785/ 0120000006

Waltham D, Hall R, Smyth HR, Ebinger CJ (2008) Basin formation by volcanic arc loading. Spec Pap Geol Soc Am 436:1 1-26. https://doi.org/10.1130/ 2008.2436(02)

Wen S, Yeh Y, Tang C et al (2015) The tectonic structure of the Song Ma fault zone, Vietnam. J Asian Earth Sci 107:26-34. https://doi.org/10.1016/j. jseaes.2015.03.046

Wessel P, Luis JF, Uieda L et al (2019) The generic mapping tools version 6. Geochem Geophys Geosyst 20:5556-5564. https://doi.org/10.1029/ 2019GC008515

Widiwijayanti C, Mikhailov V, Diament M et al (2003) Structure and evolution of the Molucca Sea area: constraints based on interpretation of a combined 
sea-surface and satellite gravity dataset. Earth Planet Sci Lett 215:135150. https://doi.org/10.1016/S0012-821X(03)00416-3

Widiwijayanti C, Tiberi C, Deplus C et al (2004) Geodynamic evolution of the northern Molucca Sea area (Eastern Indonesia) constrained by 3-D gravity field inversion. Tectonophysics 386:203-222. https://doi.org/10.1016/j. tecto.2004.05.003

Yulianto Y, Nugraha AD, Wiyono WS (2017) Hypocenters relocation using double-difference method around Molucca Collision Zone. AIP Conf Proc Doi 10(1063/1):4987044

Zenonos A, De Siena L, Widiyantoro S, Rawlinson N (2019) P and S wave travel time tomography of the SE Asia-Australia collision zone. Phys Earth Planet Inter 293:106267. https://doi.org/10.1016/j.pepi.2019.05.010
Zhang Q, Guo F, Zhao L, Wu Y (2017) Geodynamics of divergent double subduction: 3-D numerical modeling of a Cenozoic example in the Molucca Sea region, Indonesia. J Geophys Res Solid Earth 122:3977-3998. https:// doi.org/10.1002/2017JB013991

\section{Publisher's Note}

Springer Nature remains neutral with regard to jurisdictional claims in published maps and institutional affiliations.

\section{Submit your manuscript to a SpringerOpen ${ }^{\circ}$ journal and benefit from:}

- Convenient online submission

- Rigorous peer review

- Open access: articles freely available online

- High visibility within the field

- Retaining the copyright to your article

Submit your next manuscript at $\boldsymbol{\nabla}$ springeropen.com 